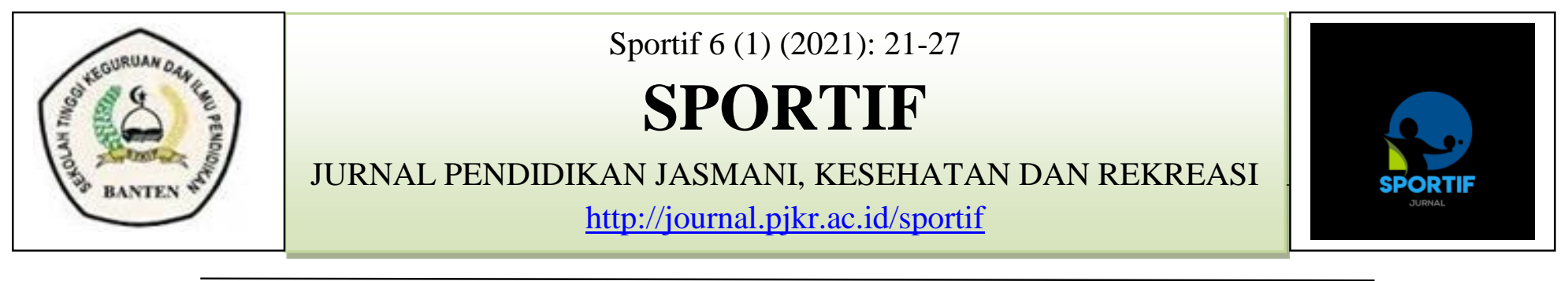

\title{
PENGARUH PENGGUNAAN METODE MENGAJAR PROBLEM SOLVING TERHADAP PENINGKATAN TEKNIK DASAR SERVIS PENDEK BULUTANGKIS
}

\author{
Pardiman \\ Program Studi Pendidikan Jasmani Kesehatan dan Olahraga \\ Sekolah Tinggi Keguruan dan Ilmu Pendidikan Banten \\ Penulis Korespondensi : Pardiman727@gmail.com
}

Artikel: Teknik Dasar Service Pendek Bulutangkis

Diterima: Februari, 2021

Dipublikasikan: Maret, 2021

\begin{abstract}
ABSTRAK
Latihan teknik dasar melakukan servis (service) bulutangkis. Servis (service) adalah pukulan pertama yang dilakukan untuk memulai suatu permainan bulutangkis. Servis merupakan teknik dasar bulutangkis yang bisa dibilang merupakan teknik pukulan yang mudah untuk dilakukan, namun masih banyak yang belum tahu tentang aturan tata cara sehingga gagal dalam cara melakukan servis. Dalam suatu pertandingan atau permainan bulutangkis, servis merupakan modal awal untuk dapat memenangkan permainan. Selain dapat menghasilkan poin/ nilai apabila lawan tidak bisa mengembalikan bola servis (shuttle cock) tersebut, servis juga dapat memberikan poin bagi pihak lawan apabila servis tersebut gagal untuk dilakukan.
\end{abstract}

Kata Kunci : Teknik dasar, Servis, Bulu Tangkis

\section{PENDAHULUAN}

Pendidikan Jasmani Olahraga dan Kesehatan adalah proses interaksi antara peserta didik dan lingkungan melalui aktivitas jasmani yang disusun secara sistematik untuk menuju manusia Indonesia seutuhnya terdiri dua makna yaitu pendidikan untu jasmani dan pendidikan untuk aktivitas jasmani.
Pendidikan jasmani merupakan bagian yang tidak terpisahkan dari pendidikan nasional yang bertujuan untuk pengembangkan kemampuan peserta didik melalui aktivitas jasmani. Tujuan yang ingin dicapai bersifat menyeluruh mencakup aspek fisik, intelektual, sosial dan moral. Pengajaran pendidikan jasmani bukan hanya sebagai kesempatan siswa untuk memperoleh kegiatan diantaranya 
kesibukan belajar sekedar untuk mengamankan siswa supaya tertib.

Pendidikan jasmani dilaksanakan guna meningkatkan kualitas manusia Indonesia sehingga memiliki tingkat kesehatan dan kebugaran yang cukup, serta dimulai sejak usia dini melalui pendidikan olahraga disekolah dan masyarakat, artinya segala usaha yang di tempuh untuk mewujudkan tujuan tersebut harus mampu diterapkan dalam setiap pengajaran pendidikan jasmani. Tujuan pendidikan dapat dicapai salah satunya dengan mengajar pendidikan jasmani atau olahraga disekolah mencakup berbagai macam cabang olahraga seperti Atletik, olahraga Air dan olahraga Beladiri. Olahraga yang dilakukan dalam proses pendidikan salah satunya adalah Bulutangkis.

Belajar mengajar adalah suatu kegiatan yang bernilai edukatif. Edukatif mewarnai interaksi yang terjadi antara guru dengan anak didik. Interaksi yang edukatif dikarenakan kegiatan belajar mengajar yang dilakukan, diarahkan untuk mencapai tujuan tertentu yang telah dirumuskan sebelum pengajaran yang dilakukan.

Pembelajaran olahraga merupakan pembelajaran yang membutuhkan keterampilan yang cukup serta kemampuan dalam mempraktikan dan memecahkan permasalahan.Kendala yang sering ditemui guru dalam mengajar olahraga diantaranya kemampuan dalam melakukan teknik dasar siswa yang cenderung rendah. Salah satu alternatif yang dapat digunakan dalam pembelajaran Matematika yaitu dengan menerapkan metode Problem Solving. Dengan menerapkan metode Problem Solving diharapkan adanya peningkatan pada keterampilan siswa dalam melakukan teknik dasar servis pendek bulutangkis.

Penggunaan gaya mengajar yang tepat bagi siswa yang sedang belajar servis akan memudahkan pelaksanaan proses belajar mengajar guna mencapai tujuan yang telah ditetapkan. Adapun salah satu gaya mengajar yang dapat digunakan untuk meningkatkan kemampuan servis pendek dalam permainan bulu tangkis yaitu dengan mengunakan gaya mengajar problem solving. Dengan belajar menggunakan problem solving diharapkan anak bisa mengekpresikan dan mempraktikann kemampuan servis pendek dalam permainan bulutangkis pada mata pelajaran pendidikan jasmani dan olaharaga.

Problem solving merupakan suatu keterampilan yang meliputi kemampuan untuk mencari informasi, menganalisis situasi dan mengidentifikasi masalah dengan tujuan untuk menghasilkan alternative sehingga dapat mengambil suatu tindakan keputusan untuk mencapai sasaran.

Permainan bulutangkis yaitu memukul bola atau shuttlecock melewati jaring (net) agar jatuh dibidang permainan lawan yang sudah ditentukan dan berusaha mencegah lawan melakukan hal yang sama dengan teknik pukulan yang bervariasi mulai dari yang relatif lambat hingga sangat cepat dan disertai dengan gerakan tipuan. Olahraga ini melatih ketepatan, kecepatan, dan strategi dalam permainan.

\section{METODE}

Metode yang digunakan dalam penelitian ini adalah studi literatur. studi 
literatur adalah penelitian yang persiapannya sama dengan penelitian lainnya akan tetapi sumber dan metode pengumpulan data dengan mengambil data di pustaka, membaca, mencatat, dan mengolah bahan penelitian.

Studi Literatur merupakan penelitian yang dilakukan oleh peneliti dengan mengumpulkan sejumlah buku buku, jurnal atau dokumen lain yang berkaitan dengan masalah dan tujuan penelitian. Teknik ini dilakukan dengan tujuan untuk mengungkapkan berbagai teori-teori yang relevan dengan permasalahan yang sedang dihadapi/diteliti sebagai bahan rujukan dalam pembahasan hasil penelitian.

\section{HASIL DAN PEMBAHASAN}

\section{Hasil}

Berdasarkan dari data yang telah dilakukan sebelumnya, didapatkan hasil dari beberapa sumber dapat disimpulkan bahwa penggunaan metode mengajar problem solving itu dapat dijadikan sebagai salah satu upaya dalam meningkatkan teknik dasar servis pendek bulutangkis.

Berdasarkan uraian diatas peneliti menyimpulkan bahwa penggunaan metode megajar problem solving merupakan metode yang efektif dalam meningkatkan teknik dasar servis pendek bulutangkis.

Pada penelitian ini metode problem solving yang diterapkan adalah untuk menyelesasikan atau meminimalisir masalah-masalah yang terjadi pada saat melakukan servis pedek (short service) bulutangkis. Oleh karena itu dalam penelitian ini juga dijelaskan tahapantahapan dalam melakukan servis pendek (short service) bulutangkis.
Tujuan menggunakan metode problem solving ini mengajak peserta didik untuk menenamkan kebiasaan-kebiasaan tertentu agar peserta mampu melatih kemampuan peserta didik dalam memecahkan masalah sehingga dapat meningkatkan kemampuan servis pendek (short service) bulutangkis dengan baik.

Dari uraian diatas dapat ditarik kesimpulan bahwa metode problem solving merupakan suatu cara mengajar dimana peserta didik mampu untuk menyelesaikan masalah dan agar siswa memiliki keterampilan atau kemampuan yang lebih maksimal dari apa yang dipelajari, maka dari itu metode problem solving sangat cocok dan alangkah baiknya dijadikan acuan bagi para guru pendidikan olahraga agar dapat meningkatkan kemampuan servis pendek bulutangkis maupun pembelajaran olahraga lainnya.

Oleh karena itu, proses pemecahan masalah mempunyai kedudukan yang sangat penting dalam upaya pencapaian tujuan, karena metode merupakan suatu cara atau jalan yang ditempuh yang sesuai dan serasi untuk menyajikan suatu hal, sehingga akan tercapai suatu tujuan pembelajaran yang efektif.

\section{Pembahasan}

Penelitian ini dilakukan untuk mengetahui pengaruh penggunaan metode mengajar problem solving terhadap peningkatan teknik dasar servis pendek bulutangkis, pada bab ini diberikan penjelasan mengenai tema penelitian dari berbagai sumber. Sumber yang digunakan terdiri dari data primer berupa buku, dan data sekunder berupa jurnal, skripsi dan tesis. 
1. Berikut merupakan penjelasan dari peneliti dari data primer:

Berdasarkan data yang tercantum dalam sumber primer metode problem solving dapat pula diartikan sebagai cara penyajian bahan pelajaran dengan menjadikan masalah sebagai titik tolak pembahasan untuk dianalisis dan disintesis dalam usaha untuk mencari pemecahan atau jawabannya oleh peserta didik.

Dengan belajar menggunakan problem solving diharapkan anak bisa mengekpresikan dan mempraktikan kemampuan servis pendek dengan baik. Metode problem solving atau metode pemecahan masalah bukan hanya sekedar metode mengajar. Ia juga merupakan suatu metode berpikir sebab dalam problem solving dapat digunakan metode-metode lain yang dimulai dengan mencari data sampai pada penarikan kesimpulan.

Dalama pelaksanaannya metode problem solving juga lebih dimengerti oleh peserta didik dalam melakukan latihan servis pendek, karena metode problem solving dalam pengajarannya yaitu mengajarkan terhadap peserta didik untuk bisa menyelesaikan permasalahan-permasalahan yang terkait dengan keterampilan melakukan servis pendek bulutangkis, bahwa dengan penggunaan metode problem solving yang tepat akan memberikan pengaruh terhadap keberhasilan atau pencapaian dari tujuan tersebut. Karena dengan metode yang sesuai maka tingkat keberhasilan akan mudah dicapai oleh peserta didik. Oleh karena itu, metode problem solving sangat tepat untuk meningkatkan teknik dasar servis pendek bulutangkis.

Inti dari metode problem solving adalah mengajarkan para siswa dalam melaksanakan tugas atau praktek.

2. Berikut merupakan penjelasan hasil peneliti dari data sekunder :

Berdasarkan hasil penelitian dari berbagai sumber terutama sumber sekunder dalam penelitian yang menggunakan metode mengajar problem solving menyatakan bahwa ada peningkatan yang signifikan dibandingkan dengan berbagai metode lainnya dan pada penelitian ini instrument yang digunakan adalah format penilaian keterampilan servis pendek.

Analisis ststistik yang digunakan adalah analisis dengan menggunakan berbagai sumber yang relevan, dan dalam rekomendasi dari penelitian ini bahwa metode mengajar problem solving dapat dijadikan salah satu upaya dalam meningkatkan pembelajaran pendidikan olahraga agar siswa dapat dengan cepat menguasai keterampilan teknik dasar servis pendek bulutangkis.

Karena dilihat dari penelitianpenelitian yang sebelumnya dengan berdasarkan hasil perhitungan dengan menggunakan analisis statistik yang digunakan adalah ststistik deskriptif. statistik ini ditujukan untuk mengumpulkan data, menyajikan data dan menentukan nilai. Selanjutnya data dilakukan pemahaman sebagai pembahasan atas permasalahan yang ditujukan dengan mengacu pada standar keterampilan servis pendek bulutangkis.

Hasil penelitian dituangkan dalam 5 kategori yaitu baik sekali, baik, 
cukup, kurang dan kurang sekali. Dari hasil penelitian-penlitian yang menggunakan analisis ini diperoleh katagori "baik".

Artinya terdapat pengaruh yang positif penggunaan metode mengajar problem solving terhadap peningkatan teknik dasar servis pendek bulutangkis.

\section{PENUTUP}

\section{Kesimpulan}

Dapat disimpulkan bahwa pembelajaran yang menggunakan metode mengajar problem solving adalah sebagai berikut :

1. Dapat meningkatkan teknik dasar servis pendek bulutangkis

2. Terbukti bahwa penggunaan metode mengajar problem solving merupakan salah satu metode yang efektif dalam upaya meningkatkan teknik dasar servis pendek bulutangkis

3. Terdapat pengaruh peningkatan teknik dasar servis pendek bulutangkis dengan menggunakan metode problem solving. Dapat disimpulkan bahwa penggunaan metode mengajar problem solving berpengarus secara signifikan terhadap peningkatan teknik dasar servis pendek bulutangkis.

\section{Saran}

Maka pada bagian akhir skripsi ini penulis akan menyampikan beberapa saran sebagai berikut :

1. Kepada para pendidik atau guru agar selalu membangkitkan motivasi anak dalam belajar karena pendidik merupakan orang tua kedua yang segala tingkah laku dan perbuatannya bisa menjadi acuan para siswa dalam berbuat.
2. Penggunaan metode mengajar problem solving memiliki dampak positif dan memberi pengaruh terhadap hasil belajar siswa-siswi terutama dalam meningkatkan teknik dasar servis pendek bulutangkis.

3. Guru Olahraga hendaknya selalu berupaya meningkatkan kualitas belajar mengajarnya, khususnya dalam peningkatan teknik dasar servis pendek bulutangkis.

4. Kepada orang tua agar selalu dapat dan terus menerus memperhatikan dan memberikan motivasi serta dorongan kepada anak-anaknya untuk lebih giat lagi dalam belajar

5. Kepada para siswa, agar berpartisipasi dalam menciptakan disiplin belajar disekolah, karena sangat bermanfaat terhadap kepribadiannya.

\section{DAFTAR PUSTAKA}

Abduh Ikhwan.dkk.2018.Meningkatkan Teknik Dasar Servis Pendek dalam Permainan Bulutangkis dengan Metode Bermain Soot And Target Pada Siswa Kelas 5A dan 5 Tolitoli. Universitas Tadulako. http://jurnal.untad.ac.id/jurnal/index.ph p/PJKR/index.

Anitah W Sri.dkk.2012. Strategi Pembelajaran di SD. Banten. Universitas Terbuka.

Aris Shoimin.2017.68 "Model pembelajaran inovatif dalam kurikulum 2013."AR-RUZZ Media.Yogyakarta.

Azwar.20180.'Penerapan Metode Drill Dalam Pembelajaran PJOK Untuk Meningkatkan Keterampilan Bulutangkis Siswa Kelas IVA SD 
Negeri 130005 Tanjung Balai Tahun Pelajaran 2018/2019”. Jurnal Guru Kita Vol.3 No.1 Desember 2018. pISSN:2548-883X.

Ayuningsih Septi.2013.Skripsi:"Pengaruh

Penggunaan Metode Pembelajaran Problem Solving Terhadap Kemampuan Berfikir Kreatif Matematika Siswa SMP Handayani Pekanbaru”. Universitas Islam Negeri Sultan Syarif Kasim Riau Pekanbaru".

Bambang I.dkk.2020. "Tingkat Kemampuan Servis Pendek Forehanda dan Kemampuan Smash Siswa Peserta Ekstrakurikuler Bulutangkis SLB Negeri Kota Bengkulu”.Universitas Dehasen Bengkulu

Budiawan

Ibnu

Nur.2016.Skripsi:"Hubungan

Kemampuan Servis Panjang dan Servis Pendek Dengan Keterampilan Bermain Tunggal Bulutangkis Siswa Kelas VII yang Mengikuti Ekstrakurikuler Bulutangkis Di SMP Negeri 2 Ngemplak Kabupaten Sleman $D I Y$ ”. Universitas Negeri Yogyakarta.

Fadillah Ahmad.2016." Pengaruh Pembelajaran Problem Solving Terhadap Kemampuan Berpikir Kreatif Matematis Siswa. Universitas Muhammadiyah Tangerang.

Gazali Novri.dkk.2019. Keterampilan Servis Pendek Bulutangkis Mahasiswa Universitas Islam Riau.Riau

Haerun Muhamad.2020." Survei Tingkat Keterampilan Servis Pendek Dalam Permainan Bulutangkis Pada Mahasiswa Bkmf Bulutangkis FIK UNM."
Hananto Tri.dkk.2015. Pendidikan Jasmani Olahraga dan Kesehatan Kelas 6 SD. Jakarta.Yudistira

Huda Miftahul, M.Pd. 2017. Model-Model Pengajaran dan Pembelajaran.Yogyakarta. Pustaka Pelajar.

Intani Andini Dwi.2019."Upaya Peningkatan Hasil Servis Pendek Dalam Permainan Bulutangkis Melalui Gaya mengajar Problem Solving Pada Siswa Kelas $X$ Di SMA Negeri Simpang Empat”. Universitas Pembinaan Masyarakat Indonesia Medan.

Isna.dkk.2019."Meningkatkan Hasil Belajar Servis Pendek pada Permainan Bulutangkis dengan Menggunakan Metode Drill Pada Siswa Kelas VIII A SMP Negeri 1 Lapandewa".Kendari

Miswan.2017.Tesis:” Analisis Konsentrasi, Percaya Diri dan Konsentrasi Mata, tangan Terhadap Pukulan Servis Pendek Cabang Olahraga Bulutangkis Pada Klub PB, Karsa Mandiri Makasar. Universitas Negeri Makasar.

Muhammad Arif ect.2011."Videographical Analysis of Short Service in Badminton". Journal of Education and Practice-vol2, No.2

Nugroho

Anton.2016.Skripsi:"Pengembangan

Tes Keterampilan Servis Pendek Bulutangkis Untuk Atlet Kelompok Umur Anak-Anak(KU11-12 Tahun), Pemula(KU13-14 Tahun), Remaja (KU 15-16 Tahun), dan Taruna (KU 17-18 
Sportif, 6 (1) (2021): 21-27

Tahun)". Universitas Negeri Yogyakarta.

Paramitha, S. T. 2018. "Revitalisasi Pendidikan Jasmani untuk Anak Usia Dini melalui Penerapan Model Bermain Edukatif Berbasis Alam". JPJO. 3 (1) (2018) 41

Shoimin Aris. 2014. 68 Model Pembelajaran Inovatif dalam Kurikulum 2013. Yogyakarta.Ar Ruzz Media

Sugiyono.2016.Metode Penelitian

Kuantitatif, Kualitatif dan $R \& D$. Bandung. Alfabeta

Sugiyono. 2016.Metode Penelitian Pendidikan Pendekatan Kuantitatif, Kualitatif dan $R$ \& $D$. Bandung. Alfabeta

Sugiyono.2010. Metode Penelitian Pendidikan Pendekatan Kuantitatif, Kualitatif dan $R \quad \& \quad D$. Bandung. Alfabeta

Sukintaka dalam Magdalena Meo.2019."Pendidikan Jasmani Olahraga dan Kesehatan dalam Membentuk NilaiNilai Karakter." Volume 6, Nomor 2 Tahun 2019.

Sulasamono Bambang S.2012." Problem Solving: Signifikansi, Pengertian, Dan Ragamnya." Program Studi S1 PPKn FKIP Universitas Kristen Satya Wacana.

Sumardi.2015. "Pengaruh Model Pembelajaran Mandiri Terhadap Hasil Belajar Servis Pendek Backhand Bulutangkis SMPN 8 Pontianak". Universitas Tanjungpura Pontianak 